\title{
13 The experience of loneliness in older adults during the COVID-19 pandemic
}

\author{
A Polish perspective
}

Ewa Grudziewska

The COVID-19 pandemic made us think more and see the consequences it has for the older adults, especially those living in nursing homes. Isolation and a sense of loneliness have become part of the everyday life of this social group. This text aims to show what factors influence the sense of loneliness of older adults experiencing isolation due to the restrictions caused by the SARS-CoV-2 pandemic. An attempt was made to indicate possible actions in this area, for example by pointing to the use of new technologies, which may significantly contribute to limiting the negative effects of the pandemic on social life. It should be borne in mind that the presented research concerns Polish older adults, however, the COVID-19 pandemic has had its irreversible impact on the lives of people all over the world, both young people and, above all, older adults.

\section{Introduction}

I recently read in a magazine that older adults are dying today not only as a result of COVID-19, but also due to fear, despair and loneliness. For many people, ageing is a difficult stage of life, and now one must additionally face feelings of endangerment and loneliness which are a certain type of borderline experience, especially in times of isolation. At times, a lack of support may lead to death. In recent times, increasingly more studies and analyses whose aim is to demonstrate the way in which the pandemic has impacted people's lives have emerged. For the purposes of this research, the way in which Polish older adults cope in the era of COVID-19 was important. Do they feel lonely? What are the determining factors of their sense of loneliness?

At the beginning of November 2020, the Seniors' Congress took place at the Maria Grzegorzewska University in Warsaw, a cyclical event whose main objective is to show how contemporary older adults' lives, the difficulties they struggle with, and also to present the initiatives which are intended 
to activate older adults. As a participant, I had the opportunity to "meet with" older adults online as the organizers were forced to do so as a result of the COVID-19 restrictions. I was greatly impressed by the older adults who actively took part in the Congress by sharing their thoughts on the current situation. It was shocking that the majority of these people coped with isolation well, showing that even in one's own home, or in a social assistance home, it is possible to actively spend time and not give up. One of the older adults, Stenia (91 years), who was a participant in the Warsaw Uprising (as a nurse), compared the current situation to the occupation of Poland during the Second World War. The conclusion of her speech was that we cannot lose hope or cheerfulness in any of these situations, that we should find joy in the smallest of things, whether this be a phone call from a scout helping older adults, delivering a warm meal or going shopping. Strength for the times of isolation that lie ahead can and should be drawn from this short conversation. Certainly, the challenge faced by people working with older adults is the large-scale use of new technologies in order to counteract social isolation and the feeling of loneliness, especially among older adults living in nursing homes (Cosco et al. 2021).

\section{Old age and loneliness, must they go hand in hand?}

A survey conducted by the National Institute of Seniors (Krajowy Instytut Gospodarki Senioralnej) in August 2020 revealed that one of the most frequent problems that older adults indicated throughout the COVID-19 pandemic was limited access to medical care (including specialists), a lack of reliable information about SARS-CoV-2, and feelings of loneliness (Health of Polish seniors during the pandemic, 2020).

Both old age and feelings of solitude are rarely mentioned in daily conversations, and this includes representatives of academic disciplines dealing with these issues. It is more frequently possible to find studies that create an image of active older adults, who manage themselves well with daily activities, have many passions and interests, who develop due to having more free time, meet with friends, take part in various initiatives organized in their place of residence and travel. It should be kept in mind that there are also older adults who struggle with several illnesses that complicate their daily lives, require assistance and support, and who experience intense solitude or even loneliness (Fopka-Kowalczyk \& Krajnik 2019).

The need for social interaction is part of human nature. Loneliness can affect anyone regardless of age or social position. It is a universal, timeless, ahistorical phenomenon and constitutes a specific sign of our times. Longterm loneliness that is not the result of our own decision may result in a depressed mood, depression, physical illnesses and a reduction in quality of life. Aside from their negative impact on well-being, loneliness and social isolation have a significant detrimental effect on the mental and physical health of older adults (Steptoe et al. 2013). The outbreak of COVID-19 has 
contributed to the loneliness of older adults who have already been affected by this problem to a great extent.

In terms of definition, loneliness and solitude are used interchangeably (De Jong Gierveld et al. 2006; Grenade \& Boldy 2008). In gerontological literature, these terms are defined as separate concepts. Thus, loneliness is "a state resulting from one's own choice and consists in spending time only with oneself," while solitude

results from an underdeveloped inner world, lack of order in which we create for ourselves a rhythm of existence different from that of the external world, other ways of measuring values and in which we are free of defeat, humiliation, triumph(...)It is a world free of suffering caused by others.

(Szczepański 1984)

It can be said that loneliness is searching for oneself, the ability to concentrate on one's inner world, and a certain type of indifference to the world. Loneliness gives a person distance, readiness to retreat and a sense of internal self-sufficiency, however, in the case of solitude, people do not find help in others and in their own inner world.

Dołęga differentiates three types of loneliness: (i) social loneliness (physical, objective), which is characterized by a lack of social bonds or belonging to a community, experiencing isolation and marginalization, a sense of being ignored or unneeded, or being unsatisfied with one's social relationships; (ii) emotional loneliness (subjective) that manifests itself in a deficit of positive emotions and relationships with significant others, and also a sense of lacking close and satisfying emotional bonds, often related with a negative self-image as a partner in social relations; and (iii), existential loneliness, which is characterized by the lack of identification with generally accepted values, life goals and norms, and also not being anchored in the world and not accepting and agreeing with a specific image of the world (Dołęga 2006; Sendyk 2011).

The Association of the Little Brothers of the Poor conducted a survey in 2018 which revealed that three in ten Poles aged 80 or older mentioned experiencing loneliness, however one in ten stated that they feel lonely very often, if not always. In the group of $80+$ older adults, half of them lived alone, $30 \%$ reported feeling lonely, 30\% did not attend social functions, $20 \%$ did not have anyone to spend their free time with, and $10 \%$ of the surveyed older adults did not have anyone they could speak with about daily life (Social situation of people aged $65+, 2020$ ). The determining factors of loneliness in older adults may include:

- cultural factors associated with e.g., changing one's place of residence (in a care and treatment facility or in a social assistance home) as the result of a deterioration in health, therefore, older adults must change their habits and adjust to the prevailing daily rhythm and habits; 
- a lonely lifestyle, which is mainly a feature of residents of large cities;

- the loss of a close relative (widowhood) - this type of loneliness impacts solitude, and may also be the cause of depression or the deterioration of one's physical condition. Older adults approach death in a different way than young people, as in a certain sense, they are closer to it, because their family members, friends and neighbours are passing away;

- awareness of the inevitability of death - it can be said that the more older adults find themselves at the end of their lives, the more they may experience feelings of loneliness and solitude. A change in temporal perspective can also be observed in older adults, i.e., concentrating on the past and present, but without a future perspective (Dąbrowska 2011: 84-90);

- the manner old age is treated in society, social reception and stereotypes;

- having a family does not prevent feelings of solitude, although it may serve as a factor that minimizes its experience (Janiszewska \& Barańska 2013).

In his analyses, Klimowicz presented the following three types of loneliness, making their occurrence dependent on their source causing them: (a) interpersonal loneliness - "longing for" caused by death or departure of close people, (b) social loneliness - triggered by isolation from or rejection by one's environment, (c) cultural loneliness - evoked by a feeling of being different in the context of functioning in a group, (d) cosmic loneliness - being "beyond" the meaning, experience of hopelessness and meaninglessness of life, (e) psychological loneliness - experiencing alienation from one's own "self." This differentiation seems to be particularly relevant when we attempt to relate it to the experience of older people. All of the categories may be attributed to the experiences of older people (Klimowicz 1988).

A consequence of isolation caused by the COVID-19 restrictions is a prolonged uncertainty about the future, a very high level of stress, hopelessness, anxiety mixed with a sense of being overwhelmed, as well as helplessness. This experience makes it difficult to cope without the assistance of one's environment. Therefore, it is important not to leave older adults alone as loneliness narrows one's field of view. This causes that attention is directed towards a person's deficits, e.g., physical illness, difficulties moving around, etc. The impact of COVID-19-related insulation is confirmed, among others, by studies by Tomaz et al. (2021) that loneliness during lockdown was higher than reported norms for this age group before the pandemic. A larger social network, more social contact, and better perceived social support seemed to be protective against loneliness and poor wellbeing. Moreover $\mathrm{Wu}$ analyzed the impact of SARS-CoV-2 isolation on the older adults and the possibility of helping maintain social relationships using technology (Wu 2020).

\section{The author's own research}

Ethical approval for this study was obtained from the informed consent and was given on the first page of the online survey or orally by telephone for 
the phone version. All participants provided consent for their participation. This study adheres to the guidelines described in the Declaration of Helsinki Ethical Principles for Medical Research Involving Human Subjects (WMA - The World Medical Association 2020). Sixty older adults took part in the study, whose number of samples was to a large extent conditioned by the COVID-19 restrictions. The average age of the participants was 76 - the youngest was 61, and the oldest, 91. Analyzing the gender of the surveyed older adults, $66.7 \%$ were women, while $33.3 \%$ were men. The largest group of participants in terms of place of residence consisted of older adults from cities with a population of more than 500,000 inhabitants $(61.7 \%)$, while the smallest group was made up of people living in cities of from 50,000 to 150,000 people $(5 \%)$. In terms of marital status, $63.3 \%$ of the surveyed older adults were widows or widowers, and only three participants were divorced (5\%). The older adults were also asked if they had children, which from the point of view of the analyzed variable, was significant. Of the surveyed older adults, $83.3 \%$ maintain contact with their children, while $16.7 \%$ did not. As far as level of education is concerned, the largest group of participants was made up of people with secondary education $(41.7 \%), 31.7 \%$ of the respondents had vocational education, $10 \%$ completed elementary education, while $16.7 \%$ possessed higher education. From among the surveyed older adults, $13.3 \%$ were professionally active, and combined their employment with retirement benefits $(11.7 \%)$ or disability allowances $(1.7 \%)$. The largest group constitutes older adults whose main source of income was retirement benefits alone $(81.7 \%)$ (Table 13.1).

For the purposes of collecting the empirical materials, the Revised Loneliness Scale (R-ULCA) adapted by Kwiatkowska et al. (2017) was used. The R-UCLA includes 20 items reflecting satisfaction or dissatisfaction with social relations, half of them being formulated positively. In previous analyses (Russell et al. 1980), each of the items had a discriminating power higher than 0.40 , and, as in the case of the previous and further version, the reliability was perfect $(\alpha=0.94)$. Originally developed as a unidimensional measure, recent research suggests more complex interpretation possibilities, i.e., treating the loneliness as a construct established through two or the three distinct factors (Austin 1983; Hawkley et al. 2005; Wilson et al. 1992). B.A. Austin (1983) proposed that the loneliness can be defined not by two, but by three factors. These three factors of loneliness can be described as follows: (1) Intimate Others, which refers to solitude, rejection, withdrawal, feeling of exclusion and the breaking of social relations with other people, it is related to the unpleasant feeling of solitary confinement and being alone in the literal meaning of the word; (2) Social Others, which refers to not having a social network to connect with and lack of the feeling of closeness in relation with other people (in terms of their availability), it refers to the lack of contact with close relatives or trusted people who form a sense of safety and support; and (3) Belonging and Affiliation, which refers to a lack of a sense of group identity (affiliation) and bonds with a community, it refers to 
Table 13.1 The features of the surveyed older adults

\begin{tabular}{|c|c|c|c|}
\hline & & $N$ & $\%$ \\
\hline \multirow[t]{2}{*}{ Sex } & Women & 40 & 66.7 \\
\hline & Men & 20 & 33.3 \\
\hline \multirow[t]{4}{*}{ Place of residence } & Village & 9 & 15.0 \\
\hline & City up to 50,000 people & 11 & 18.3 \\
\hline & City of from 50 to 150,000 people & 3 & 5.0 \\
\hline & City over 500,000 people & 37 & 61.7 \\
\hline \multirow[t]{4}{*}{ Marital status } & Miss/bachelor & 3 & 5.0 \\
\hline & Married & 16 & 26.7 \\
\hline & Widow & 38 & 63.3 \\
\hline & Divorce & 3 & 5.0 \\
\hline \multirow{2}{*}{ Maintain contact with children } & Yes & 50 & 83.3 \\
\hline & No & 10 & 16.7 \\
\hline \multirow{4}{*}{ Education } & Primary & 6 & 10.0 \\
\hline & Vocational & 19 & 31.7 \\
\hline & Secondary & 25 & 41.7 \\
\hline & Higher & 10 & 16.7 \\
\hline \multirow{2}{*}{ Professional situation } & Professionally active & 8 & 13.3 \\
\hline & Professionally inactive & 52 & 86.7 \\
\hline \multirow[t]{5}{*}{ Surveyed } & Retirement benefits & 1 & 1.7 \\
\hline & Retirement benefits & 49 & 81.7 \\
\hline & Disability allowances & 2 & 3.3 \\
\hline & $\begin{array}{l}\text { Employment with retirement } \\
\text { benefits }\end{array}$ & 7 & 11.7 \\
\hline & $\begin{array}{l}\text { Employment with disability } \\
\text { allowances }\end{array}$ & 1 & 1.7 \\
\hline
\end{tabular}

the weaker links with a social group and feeling more like an individual than a part of a group (Austin 1983; Hawkley et al. 2005).

The obtained results of the study were analyzed statistically. The values of the analyzed measurable parameters were represented by the average value and standard deviation, while the unmeasurable parameters were represented by numbers and percentage. The independent student's t-test was applied investigating the differences between the two groups. The Pearson's correlation coefficient and linear regression were used to verify the dependencies between the variables. The statistical significance was $p<0.05$. The database and statistical test were conducted in the SPSS 27.0 package.

\section{Results}

At the outset, it was decided to determine the general average result for loneliness and its dimensions. Detailed results are presented in Table 13.2.

The conducted analyses revealed that in the Intimate Others scale, the minimum score was 10 points, the maximum score was 35 points, while the average score amounted to $\mathrm{M}=22.83$. In terms of Social Others, the minimum score was 5 points, the maximum score was 17 points, and the average 
Table 13.2 Loneliness: descriptive statistics

\begin{tabular}{lrrrr}
\hline & \multicolumn{1}{c}{$M$} & \multicolumn{1}{c}{ SD } & \multicolumn{1}{c}{ Min } & Max \\
\hline Intimate Others & 22.83 & 5.82 & 10.00 & 35.00 \\
Social Others & 8.77 & 3.49 & 5.00 & 17.00 \\
Belonging and Affiliation & 10.98 & 3.38 & 6.00 & 21.00 \\
Loneliness & 42.58 & 11.18 & 21.00 & 67.00 \\
\hline
\end{tabular}

Table 13.3 Gender and loneliness in the surveyed older adults

\begin{tabular}{|c|c|c|c|c|c|c|}
\hline & \multicolumn{2}{|c|}{ Women } & \multicolumn{2}{|l|}{ Men } & \multirow[t]{2}{*}{$t$} & \multirow[t]{2}{*}{$P$} \\
\hline & $M$ & $S D$ & $M$ & $S D$ & & \\
\hline Intimate Others & 22.80 & 6.29 & 22.90 & 4.91 & -0.062 & 0.951 \\
\hline Social Others & 8.72 & 3.20 & 8.85 & 4.09 & -0.130 & 0.897 \\
\hline $\begin{array}{l}\text { Belonging and } \\
\text { Affiliation }\end{array}$ & 10.95 & 3.21 & 11.05 & 3.79 & -0.107 & 0.915 \\
\hline Loneliness & 42.47 & 11.16 & 42.80 & 11.50 & -0.105 & 0.917 \\
\hline
\end{tabular}

score amounted to $\mathrm{M}=8.77$. As far as Belonging and Affiliation is concerned, the minimum scare was 6 points, the maximum score was 31 points, while the average score amounted to $\mathrm{M}=10.98$. In terms of Loneliness, the minimum score amounted to 21 points, the maximum score was 67 points, and the average score was $\mathrm{M}=42.58$.

The next step in the conducted analyses was to determine if the surveyed older adults' gender differentiated their sense of loneliness. The analyses conducted by using the (independent) student's t-test revealed that this sociodemographic variable does not statistically significantly differentiate loneliness. It can be observed that a slightly higher average score was obtained by the surveyed men in all three of the analysed dimensions, i.e., Intimate Others, Social Others and Belonging and Affiliation, as well as in Loneliness. Detailed data is presented in Table 13.3.

It was then decided to verify if the age of the surveyed older adults significantly differentiates their sense of loneliness. As a result, as a dividing point for comparing the groups, the average age of 76 was adopted. The group of people under 76 consisted of 29 older adults, while 31 people were found in the 76+ group. Detailed results are presented in Table 13.4.

The independent student's t-test revealed statistically significant differences between the compared groups of older adults in terms of age. The conducted analysis revealed that people aged 76 and older $(M=25.71)$ experience Intimate Others to a greater extent than participants under $76(\mathrm{M}=19.76$; $\mathrm{p}<0.000)$. As far as Social Others is concerned, significant differences between the compared groups of older adults were also observed. It turns out 
Table 13.4 Age and loneliness in the surveyed older adults

\begin{tabular}{lrrrrrr}
\hline & Up to 76 years & \multicolumn{1}{c}{$\begin{array}{l}76 \text { years and } \\
\text { more }\end{array}$} & $t$ & $P$ \\
\cline { 1 - 5 } & $M$ & $S D$ & \multicolumn{1}{c}{$M$} & $S D$ & & \\
\hline Intimate Others & 19.76 & 3.86 & 25.71 & 5.92 & -4.576 & $0.000^{*}$ \\
Social Others & 7.59 & 3.04 & 9.87 & 3.57 & -2.661 & $0.010^{*}$ \\
Belonging and Affiliation & 10.07 & 3.16 & 11.83 & 3.41 & -2.082 & $0.042^{*}$ \\
Loneliness & 37.41 & 8.51 & 47.42 & 11.32 & -3.849 & $0.000^{*}$ \\
\hline
\end{tabular}

** Significant at 0.01

*Significant at 0.05

Table 13.5 Maintaining contact with children and loneliness in the surveyed older adults

\begin{tabular}{|c|c|c|c|c|c|c|}
\hline & \multicolumn{2}{|c|}{$\begin{array}{l}\text { Contact with } \\
\text { children }\end{array}$} & \multicolumn{2}{|c|}{$\begin{array}{l}\text { Not contact } \\
\text { with children }\end{array}$} & \multirow[t]{2}{*}{$t$} & \multirow[t]{2}{*}{$P$} \\
\hline & $M$ & $S D$ & $M$ & $S D$ & & \\
\hline Intimate Others & 22.06 & 5.84 & 26.70 & 4.11 & -2.391 & $0.020 *$ \\
\hline Social Others & 8.24 & 3.22 & 11.40 & 3.75 & -2.756 & $0.008^{*}$ \\
\hline Belonging and Affiliation & 10.64 & 3.33 & 12.70 & 3.27 & -1.791 & 0.079 \\
\hline Loneliness & 40.94 & 10.82 & 50.80 & 9.58 & -2.676 & $0.010^{*}$ \\
\hline
\end{tabular}

*Significant at 0.05

that older adults aged 76 and older experience Social Others to a greater extent $(M=9.87)$ than people under 76 years of age $(M=7.59 ; p<0.010)$. A complete or partial lack of Belonging and Affiliation is more frequently a feature of older adults aged 76 and older $(M=11.83)$, and the conducted analyses revealed statistically significant differences $(p<0.042)$. In terms of Loneliness, the difference is also significant, in which a higher intensity of this variable is present in older adults from $76+$ group $(p<0.000)$. Similar results were obtained in research conducted by Nowicki et al. (2018), in which it turned out that the older a person is, the higher the sense of loneliness.

Next, it was decided to verify whether maintaining contact with children differentiates the surveyed older adults' sense of loneliness during the COVID-19 pandemic. Therefore, the independent student's t-test was applied. The conducted statistically analyses showed differences in the surveyed group of older adults in relation to two scales. Detailed data is presented in Table 13.5.

The obtained results should not come as a surprise, because, as it turns out significantly higher average scores are characteristic of the surveyed older adults who do not maintain contact with their children. In terms of Intimate Others, the difference is significant at the level of $p<0.020$, however, in Social Others $\mathrm{p}<0.008$. Significant differences were not noted in 
Table 13.6 Loneliness and age, gender and contact with children: correlations

\begin{tabular}{llll}
\hline & Sex & Age & Contact with children \\
\hline Intimate Others & - & $0.515^{*}$ & $0.299^{* *}$ \\
Social Others & - & $0.330^{* *}$ & $0.340^{*}$ \\
Belonging and Affiliation & - & $0.264^{* *}$ & - \\
Loneliness & - & $0.451^{*}$ & $0.331^{* *}$ \\
\hline
\end{tabular}

* Correlation is significant at the 0.01 level (2-tailed).

** Correlation is significant at the 0.05 level (2-tailed).

- Correlation is not significant.

Table 13.7 Regression results

\begin{tabular}{|c|c|c|c|c|c|}
\hline & $\begin{array}{l}\text { Dependent } \\
\text { variable }\end{array}$ & $\begin{array}{l}\text { Intimate } \\
\text { others }\end{array}$ & $\begin{array}{l}\text { Social } \\
\text { others }\end{array}$ & $\begin{array}{l}\text { Belonging } \\
\text { and } \\
\text { affiliation }\end{array}$ & Loneliness \\
\hline & $\begin{array}{l}\text { Independent } \\
\text { variables }\end{array}$ & $\beta$ & $B$ & $\beta$ & $\beta$ \\
\hline Sex & & - & - & - & - \\
\hline Age & & $0.518^{*}$ & $0.317 * *$ & - & $0.447^{*}$ \\
\hline $\begin{array}{l}\text { Contact with } \\
\text { children }\end{array}$ & & $0.246^{* *}$ & $0.310^{* *}$ & - & $0.286^{* *}$ \\
\hline$N(\mathrm{df})$ & & 56 & 56 & 56 & 56 \\
\hline $\mathrm{R}^{2}$ & & 0.341 & 0.211 & 0.115 & 0.298 \\
\hline
\end{tabular}

* Significant at 0.01 .

** Significant at 0.05 .

- Not significant.

Belonging and Affiliation. Maintaining contact with children significantly differentiated Loneliness $(\mathrm{p}<0.010)$.

It was also decided to verify, by means of the Pearson's correlation coefficient, which sociodemographic variables correlate with the sense in loneliness of the surveyed older adults. The obtained results (Table 13.6) show that the age of the surveyed older adults reveal significant correlations between all of the dimensions of loneliness and the global sense of loneliness. On the other hand, no correlations were found between any of the analysed dimensions of loneliness, however, maintaining contact with children significantly correlates with Intimate Others, Social Others, and Loneliness.

Finally, it was verified whether the analysed sociodemographic variables create models with loneliness and its dimensions. Therefore, the regression analysis was applied (Table 13.7). The obtained results showed that both age and maintaining contact with children are predictors of loneliness in 
older adults. The variables in the model explain $30 \%$ of the variances for Loneliness, $21 \%$ of variances for Social Others and $34 \%$ of the variances for Intimate Others. The most significant predictor of Loneliness is the age of the surveyed older adults $(\beta=0.447)$, as in the case of Intimate Others $(\beta=0.518)$ and Social Others $(\beta=0.317)$.

\section{For further discussions...}

The conducted analyses showed that older adults are characterized by a low level of loneliness both in the global dimensions and in terms of Intimate Others, Social Others and Belonging and Affiliation, which revealed the averages for the surveyed sample. Looking at the differences in terms of loneliness in relation to the sociodemographic variables such as age, gender or contact with children, it was observed that gender does not determine loneliness in older adults. However, the intensity of loneliness and its dimension increases with age, which is consistent with research carried out in this age group, i.e., people $60+$, confirmed by studies conducted by Perissinotto et al. (2012) and Singh and Misra (2009). Maintaining contact with close relatives (children) also significantly contributes to loneliness in older adults. These dependencies were confirmed by the Pearson's correlation coefficient and the linear regression analysis. Of course, these findings may be interpreted in relation to this specific sample and not to the entire population of older adults, however, this is certainly a trend that should be verified in a larger number of participants. How can loneliness and solitude be prevented in older adults lives? In terms of the consequences of isolation caused by COVID-19, it is obvious that all age groups have been negatively affected. Is it possible to avoid this type of effects both in terms of physical, but above all, mental health? With all certainty, a brief telephone conversation with close friends and relatives (children, grandchildren, friends, or acquaintances) would be a "medicine" for many people, after all, daily conversations are a very important elements of our lives. Mobile phones with video functions, computers with Internet access are available (provided that one is able to operate them, although increasingly more older adults are perfectly able to manage themselves with new technologies). In the absence of close friends or relatives, assistance is provided by non-governmental organizations or special hotlines, e.g. The National Helpline for Older adults operating under the auspices of the Association of the Little Brothers of the Poor.

In Poland, a series of activities have been introduced in response to the implemented restrictions, which are aimed at supporting older adults in their daily functioning, e.g., delivering warm meals, shopping, buying medication. These activities are carried out by social assistance centres and non-governmental organizations. At the governmental level, the Solidarity Assistance Corps for Seniors has been established, thanks to which Polish older adults can receive necessary help throughout the pandemic. Within the framework of support, volunteers may assist with shopping, taking dogs for a walk, housework, or dealing with official matters, and perhaps most 
importantly, simply speaking with older adults. The need to have conversations with others may be the impulse for acquiring knowledge and new skills by people who have not had the need to use new technology.

\section{References}

Austin, B.A. (1983). Factorial Structure of the UCLA Loneliness Scale. Psychological Reports, 53, 883-889. DOI: 10.2466/pr0.1983.53.3.883.

Cosco, T., Fortuna, K., Wister, A., Riadi, I., Wagner, K., \& Sixsmith, A. (2021). COVID-19, Social Isolation, and Mental Health Among Older Adults: A Digital Catch-22. Journal of Medical Internet Research, 23(5), e21864. DOI: 10. 2196/21864.

Dąbrowska, P. (2011). Samotność osób starszych i sposoby jej przeciwdziałania. Kwartalnik Naukowy, 6(2), 84-90.

De Jong Gierveld, J., van Tilburg, T.G., \& Dykstra, P.A. (2006). Loneliness and social isolation. In D. Perlman \& A. Vangelisti (Eds.), The Cambridge handbook of personal relationships (pp. 485-500). Cambridge, UK: Cambridge University Press.

Dołęga, Z. (2006). Samotność młodzieży - analiza teoretyczna i studia empiryczne. Katowice: Wydawnictwo Uniwersytetu Śląskiego.

Fopka-Kowalczyk, M., \& Krajnik, M. (2019). Expectations and self-care of family members in palliative care. The analysis of needs and workshop plan. Educational Studies Review, 29(2), 91-110.

Grenade, L., \& Boldy, D. (2008). Social isolation and loneliness among older people: Issues and future challenges in community and residential settings. Australian Health Review, 32(3), 468-478.

Hawkley, L.C., Browne, M.W., \& Cacioppo, J.T. (2005). How can I connect with thee?: Let me count the ways. Psychological Science, 16, 798-804. DOI: 10.1111/j.1467-9280.2005.01617.x

Janiszewska, M., \& Barańska, A. (Eds.) (2013). Samotność i osamotnienie osób starszych wiekiem. W: J. Zimny (red.). Samotność: rzeczywistość czy fikcja. Stalowa Wola: Wyd. KUL.

Klimowicz, G. (1988). Przeciwko bezradnejsamotności. Warszawa: Nasza Księgarnia.

Kwiatkowska, M.M., Rogoza, R., \& Kwiatkowska, K. (2017). Analysis of the psychometric properties of the Revised UCLA Loneliness Scale in the Polish adolescent sample. Current Issues in Personality Psychology, 5, 1-7. DOI: 10.5114/ cipp. 2017.69681

Perissinotto, C.M., Cenzer, I.S., \& Covinsky, K.E. (2012). Loneliness in older persons: A predictor of functional decline and death. Archives of Internal Medicine, 172(14), 1078-1083.

Russell, D.W., Peplau, L.A., \& Cutrona, C.E. (1980). The revised UCLA loneliness scale: Concurrent and discriminant validity evidence. Journal of Personality and Social Psychology, 39, 472-480. DOI: 10.1037/0022-3514.39.3.472

Sendyk, M. (2011). Osamotnienie jako konsekwencje zaburzeń więzi emocjonalnych w rodzinie. Wychowanie w Rodzinie, 4, 139-150.

Singh, A., \& Misra, N. (2009). Loneliness, Depression and sociability in old age. Industrial Psychiatry Journal, 18(1), 51-55.

Social situation of people aged $65+-$ wyniki badania zrealizowanego dla Stowarzyszenia mali bracia Ubogich przez ARC Rynek i Opinia, https://www. malibracia.org.pl/aktualnosci/samotnosc-polskiego-seniora/ (access: 12.12.2020). 


\section{Ewa Grudziewska}

Steptoe, A., Shankar, A., Demakakos, P., \& Wardle, J. (2013). Social isolation, loneliness, and all-cause mortality in older men and women. Proceedings of the $\mathrm{Na}$ tional Academy of Sciences of the United States of America, 110(15), 5797-5801.

Szczepański, J. (1984). Sprawy ludzkie. Warszawa: Wydawnictwo Czytelnik.

Tomaz, S.A., Coffee, P., Ryde, G.C., Swales, B., Neely, K.C., Connelly, J., Kirkland, A., McCabe, L., Watchman, K., Andreis, F. et al. (2021). Loneliness, wellbeing, and social activity in scottish older adults resulting from social distancing during the COVID-19 pandemic. International Journal of Environmental Research and Public Health, 18, 4517.

Wilson, D., Cutts, J., Lees, I., Mapungwana, S., \& Maunganidze, L. (1992). Psychometric properties of the Revised UCLA Loneliness Scale and two short-form measures of loneliness in Zimbabwe. Journal of Personality Assessment, 59, 72-81. DOI: 10.1207/s15327752jpa5901_7

WMA - The World Medical Association. WMA Declaration of Helsinki-Ethical PrinciplesforMedicalResearchInvolvingHumanSubjects. Availableonline:https:// www.wma.net/policies-post/wma-declaration-of-helsinki-ethical-principlesfor-m edical-research-involving-human-subjects/ (access: 9.01. 2021).

$\mathrm{Wu}, \mathrm{B}$. (2020). Social isolation and loneliness among older adults in the context of COVID-19: a global challenge. Glob Health Res Policy 5, 27. DOI: https://doi. org/10.1186/s41256-020-00154-3

Zdrowie polskich seniorów w czasie pandemii. Krajowy Instytut Gospodarki Senioralnej, Warszawa 16.09.2020 - https://kigs.org.pl/wp-content/uploads/2020/09/ 20200902_Raport_Zdrowie-w-pandemii-002.pdf (access: 6.01.2021). 